HANNA KARASZEWSKA

ORCID 0000-0002-7250-8722

Joanna Rajewska de Mezer

ORCID 0000-0003-1870-0876

EWELINA SiLECKA-MAREK

ORCID 0000-0003-3710-0470

Uniwersytet im. Adama Mickiewicza

w Poznaniu

\title{
INCREASING ROLE OF MEDIATION IN CONFLICT RESOLUTION IN THE FAMILY
}

\begin{abstract}
Aвsтract. Karaszewska Hanna, Rajewska de Mezer Joanna, Silecka-Marek Ewelina, Increasing Role of Mediation in Conflict Resolution in the Family [Rosnąca rola mediacji w rozwiązywaniu konfliktów w rodzinie]. Studia Edukacyjne nr 53, 2019, Poznań 2019, pp. 285-299. Adam Mickiewicz University Press. ISSN 1233-6688. DOI: $10.14746 /$ se.2019.53.16
\end{abstract}

Conflict-related and disputable situations have been present in our lives since ancient times, when people have become aware of the need to protect their rights and interests, sometimes at odds with the aspirations of others. The conflict that emerges between people disturbs their relationships and poses a threat to the proper functioning of people, bringing with them negative emotions. However, it can be an opportunity for development, be treated as a change in interpersonal relationships and can ultimately produce positive effects. Mediation offers a possibility of converting the negative aspects of the conflict into constructive solutions.

Being voluntary, confidential, non-formal, out-of-court proceedings, it enables the parties to come to an agreement, offering them the opportunity to actively participate in shaping the legal and social situation and exercising their rights and interests in the spirit of consensus. In the mediation process, the parties use the support of a professional, impartial, neutral mediator. The authors of the article promote the idea of mediation with full conviction that it is a valuable and effective way for conflicted parties and third parties and their relatives to reach a consensus on various issues, including family matters.

Key words: mediation, mediation proceedings, mediator, conflict, dispute resolution

Since ancient times, people have been coming across situations where there is a difference of opinion or interests that causes conflicts between individuals and social groups. 
A conflict is a phenomenon that people experience on various levels of their functioning. The characteristics of this phenomenon are influenced by the frequency, intensity level, solutions adopted and consequences of conflict situations. ${ }^{1}$

Everyday conflicts, related both to one's family and one's functioning in the widely-understood society, school, peer, work and business environments, disrupt interpersonal relations and pose a threat to the correct functioning of an individual.

When starting various types of interpersonal relationships (e.g. with one's colleagues, spouse, family and in professional contexts), an individual often enters a world that is different from theirs with respect to values, interests and objectives. The individual comes across other people's actions that may be contradictory or at variance with their own objectives. ${ }^{2}$

A conflict of interests leads to a situation where the parties that depend on each other can only notice the differences that are impossible to reconcile. The conflict is accompanied by negative emotions; yet, it should also be treated as a chance to grow and as a breakthrough in interpersonal relations. When it is created, it means that those involved perceive each other as an obstacle in achieving their objectives, and as ones who have no positive features, cause dislike and anger. ${ }^{3}$ Publications on the subject follow C.W. Moore's distinction into relationship, data, interest, structural and value conflicts. ${ }^{4}$ And yet, as noted by A. Zienkiewicz, not only can conflicts antagonize but they can also bring individuals together, and above all they reflect the dynamics of change and development in the community. They can unite and have a constructive influence or fulfil destructive functions. ${ }^{5}$ Solving a conflict, looking at it from the other party's perspective or simply making an attempt to meet the conflicted party are all possible thanks to the institution of mediation.

The idea of conflict resolution using alternative methods (alternative dispute resolution - $\mathrm{ADR}^{6}$ ) originated in ancient times, whereas compensation and conflict resolution by means of negotiation and agreement between

${ }^{1}$ S. Byra, Konflikt interpersonalny - istota i funkcje, [in:] Profesjonalny mediator. Zostań nim. Poradnik metodyczny, Ed. A. Lewicka, Lublin 2008, p. 171.

${ }^{2}$ Ibidem, p. 172.

${ }^{3}$ H. Karaszewska, Mediacja jako dobrowolny sposób rozwiązywania konfliktów w rodzinie, [in:] Horyzonty pedagogiki resocjalizacyjnej, Eds. A. Barczykowska, M. Muskała, Poznań 2017, p. 409-423.

${ }^{4}$ More: Ch.W. Moor, The Mediation Process. Practical Strategies for Resolving Conflict, Third Edition, San Francisco 2003; M. Szczepański, Propedeutyka konfliktu, [in:] Negocjacje wśród ważnych zagrożeń i ukrytych możliwości, Eds. W.J. Paluchowski, R. Kaczmarek, M. Skrzypczak, Wydawnictwo Naukowe UAM, Poznań 2006.

${ }^{5}$ A. Zienkiewicz, Studium mediacji. Od teorii ku praktyce, Warszawa 2007, p. 21.

${ }^{6}$ Alternative ADR methods of conflict resolution mean "amicable and conciliatory ways of solving conflicts and dispute based on the idea of striving after agreement and finding a com- 
the perpetrator and the victim, families, clans or tribal groups have been known since before organized state structures appeared. ${ }^{7}$ Jewish, Christian, Buddhist, Islamic and Hindu cultures once worked out and continue to use amicable methods of conflict resolution as part of the so-called arena of conflict. ${ }^{8}$ ADR was created in the United Kingdom, and its assumptions were intensively developed back in the late $19^{\text {th }}$ and early $20^{\text {th }}$ centuries in the United States. In the 1970s, the potential of alternative methods started to be also used in France, Italy, Spain, and Central and Eastern Europe. In Poland, ADR flourished especially in the 1990s. ${ }^{9}$ From the formal point of view, alternative methods of dispute resolution can be divided into primary and derivative. Med-arb, arb-med, neutral fact finding, med.-fact finding, early neutral evaluation, neutral/confidential listener, litigation management, corporate ombudsman and Multi-Steps ADR all belong to mixed (derivative) forms. Among the primary forms, mediation is the most distinctive one, and apart from it, negotiations, conciliation and arbitration are distinguished. ${ }^{10}$

Since time immemorial, mediation has been perceived as a constructive form of solving conflicts in many cultures. It has been used not only in the process of arriving at a compromise in religious disputes, but also in secular conflicts. ${ }^{11}$

Mediation is defined as a process or form of intervention in a dispute and its objective is to help people communicate. The "mediation" term comes from the Greek word "medos", meaning intermediary, neutral and not belonging to any of the parties. In Latin, the word "mediatio" means agency, i.e. a procedure of intermediating in a dispute that should lead the conflicted parties to an agreement. ${ }^{12}$ On the other hand, the Italian word "mediare" is translated as intermediating in a dispute. ${ }^{13}$

promise to solve a conflict situation" after: A. Kalisz, A. Zienkiewicz, Mediacja sądowa i pozasądowa. Zarys wykładu, Warszawa 2009, p. 26.

7 A. Matysiak-Błaszczyk, J. Rajewska de Mezer, Mediacja jako szansa pojednania sprawcy i ofiary przestępstwa w sprawach z zakresu prawa karnego, Studia Edukacyjne, 2016, 39, p. 171.

8 S.M. Kulag (Ed.), Mediacja jako alternatywa dla sądu, a usprawnienie pracy wymiaru sprawiedliwości. Uwagi na tle instytucji mediacji w systemie prawa polskiego, Brześć 2007, p. 88 and n.

${ }^{9}$ More: H. Przybyła-Basista, Mediacje rodzinne w konflikcie rozwodowym. Gotowość i opór matżonków a efektywność procesu mediacji, Katowice 2006, p. 17; A. Kalisz, A. Zienkiewicz, Mediacja sadowa i pozasadowa, p. 28 and n.

10 See: A. Mól, Pojęcie i znaczenie alternatywnych metod rozstrzygania sporów, Przegląd Prawa Handlowego, 2001, 12, p. 31; M. Romanowska, Miejsce mediacji wśród ADR w Wielkiej Brytanii i Polsce, ADR, 2010, 1, p. 95.

${ }^{11}$ E. Grudziewska, A. Lewicka-Zelent, Kompetencje mediacyjne w profesji pracownika socjalnego, Warszawa 2015, p. 25.

${ }^{12}$ E. Smoktunowicz, Wielka encyklopedia prawa, Białystok - Warszawa 2000, p. 440.

13 See: M. Bobrowicz, Mediacje gospodarcze - jak mediować i przekonywać, Warszawa 2004, p. 13; Stownik jezzyka polskiego PWN, Warszawa 2006. 
Mediation is often called a procedure of conflict resolution where the mediator accompanies the participants/parties in the process of arrangements by helping them facilitate communication, defining contentious issues, stating the needs and interests of each party, and - if they are willing - working out a mutually conscious and satisfying agreement. Mediation is used in juvenile, penal and civil cases. It can thus be applied in a conflict situation that occurred as a result of committing a punishable act, crime, or conflict in the family (e.g. divorce, problems with regulating contacts between parents and their child), as well as in a conflict situation that occurred in a peer group, at school or at work. As mediation is used in such a variety of situations, one can say that it creates a possibility of reaching an agreement by the conflicted individuals. It is not a form of therapy or meeting during which the mediator hands ready-made solutions to the parties; it can, however, allow the conflicted parties to hear and listen to the needs of each of them. Mediation is not equivalent to counselling or arbitration, either; nor does it serve as a panacea to solve every conflict. It creates an opportunity for an individual to present the problem from their own perspective and decide on the case, and at the same time take on responsibility for their own actions and decisions. It makes it possible to notice the perspective of the other party, and above all understand it. Mediation also allows the parties to minimize their fear of the behaviour of the party that they are at conflict with. It also makes it possible for an individual to understand the damage caused and forgive the harm experienced. It is also an opportunity to improve disrupted relations, or even rebuild them and reach compensation faster than in case of court proceedings. Mediation respects the interests of both parties, and the solutions are actively worked out by the conflicted individuals themselves. ${ }^{14}$ According to Ch.W. Moore, mediation can be understood as a method of restoring relations of trust and mutual respect between the parties and as an intervention of a third person who is not involved in the conflict, is accepted and is not entitled to make decisions related to solving the dispute. ${ }^{15}$ The process of mediation can decrease tension and anger levels, and clarify misunderstandings that were the basis of the conflict that occurred. "It was proved that not only does mediation make it possible to calmly agree on the rules of further co-existence, but, most importantly, it also allows the members of one family to stay in contact" ${ }^{16}$ The Recommendation No R (98) of the Committee of Ministers of the Council of Europe passed on 21 Jan-

${ }^{14}$ H. Karaszewska, Mediacja jako dobrowolny sposób, p. 416.

${ }^{15}$ Ch.W. Moor, The Mediation Process, p. 15.

${ }^{16}$ M. Romanowska, Miejsce mediacji, p. 110-111 quoted after: A. Bieliński, A. Kaftańska, Kilka uwag na temat mediacji rodzinnych, Kwartalnik ADR, 2011, 3, p. 25. 
uary 1998 underlined that using mediation between family members can contribute to improving communication and decreasing the level of conflict between them, and ensuring the continuity of contacts between parents and children. It can also decrease the social and economic costs of divorce for the parties involved and the state, as well as shorten the time that would otherwise be necessary to solve the conflict. ${ }^{17}$ Phrasing one exhaustive definition of mediation is difficult due to its multiple types and diversity of objectives that it can fulfil. ${ }^{18}$ To make a synthesis of the features of this form of approach to a conflict, one can say that:

Mediation is a voluntary, confidential, non-formalized and out-of-court form of proceedings where it is possible for the parties to reach an agreement or agree to a settlement. It gives the option to actively participate in shaping the legal and social situation of the participants and arrive at a consensus that takes into account their rights and interests with the support of a professional, impartial and neutral mediator. Mediation is carried out in many cases; it has also been used at schools. It was the recommendation of the Ombudsman for Children to introduce mediation to Polish schools and facilities, as mediation was recognized to be an alternative method to traditional ways of dispute resolution that introduces the culture of dialogue and sense of joint responsibility in shaping the atmosphere at school. ${ }^{19}$

Irrespective of the type of the conflict, there is a set of repeatable rules that characterize mediation:

a. Freedom - the parties agree to participate in mediation proceedings. The consent can be withdrawn at any stage of the mediation by each party, which the parties have to be informed about at the beginning. The participants of mediation proceedings cannot be under any form of pressure or force linked to their participation in mediation.

b. Impartiality - the parties of mediation have equal rights and should be treated equally.

c. Confidentiality - the course of mediation proceedings is protected by secrecy.

d. Neutrality - the mediator cannot impose their own proposals for dispute resolution on the parties. The agreement is worked out by the parties themselves. The mediator cannot derive any benefits from the subject of negotiation.

17 The Recommendation is available at: http://ms.gov.pl/pl/dzialalnosc/mediacje/publikacje [accessed on: 16.01.2019].

${ }_{18}$ See: E. Gmurzyńska, R. Morek, Wprowadzenie, [w:] Mediacje. Teoria i praktyka, Warszawa 2009.

19 Standardy mediacji rówieśniczej i szkolnej w szkołach i innych placówkach oświatowych, Rzecznik Praw Dziecka, Warszawa 2017, p. 2-3. 
e. Acceptability - the parties have to accept the person acting as their mediator and their assistance in reaching an agreement. They can also agree with the mediator on the rules for mediation that they should obey in the course of mediation. ${ }^{20}$

f. Selflessness - the mediator cannot use their contact with the parties for their own benefit.

g. Professionalism - the mediator should graduate from specialized training in mediation and use their knowledge and skills for the best interest of the parties.

h. Respect - the mediator makes sure that the parties treat each other with respect and talk about their behaviour and decisions without judging each other. ${ }^{21}$

The active participation of the conflicted parties in designing the dispute resolution makes it possible for them to accept responsibility for the agreement reached and creates the sense of influence on one's life which is so important for self-determination.

The parties involved in a conflict have detailed knowledge about their situation, needs and possibilities, which is why their active participation in creating a solution is an important value. The mediator supports and moderates the conversation, sets a direction for the line of thinking, makes sure deadlock is avoided in the proceedings, but cannot propose or impose solutions on the parties. Although an expert in the procedure of mediation, the mediator is not a specialist in presenting ready-made solutions for a problem that occurred. They are a "stimulator", a sort of "intermediary with factual knowledge" who facilitates it for the parties to reach an agreement by guarding the principle of legality. ${ }^{22}$ Using mediation as a form of solving a conflict carries a range of advantages for its participants in each environment. Above all, mediation:

1. Makes it possible for the parties to share information on difficult experiences.

2. Makes it possible to present the problem from one's own perspective.

3. Makes it possible to decide on one's own case, at the same time taking over responsibility for one's own actions and decisions.

4. Creates an opportunity to notice the other party's perspective and understand not only one's feelings and needs, but also the feelings and needs of the other party.

5. Makes it possible to minimize one's fear of the other party's behaviour.

6. Makes it possible to understand the damage and forgive the harm done.

${ }^{20}$ M. Kuć, Wiktymologia, Warszawa 2010, p. 135-136.

${ }^{21}$ The last three rules were added by Polskie Centrum Mediacji [Polish Mediation Centre] in Kodeks Etyki Mediatora [Code of Mediator's Ethics], Warszawa 2006.

${ }^{22}$ A. Matysiak-Błaszczyk, J. Rajewska de Mezer, Mediacja jako szansa, p. 170. 
7. Creates an opportunity to improve and rebuild an upset relationship.

8. Respects the interests of both parties and makes it possible to work out solutions that are beneficial for both parties.

9. Creates favourable conditions for reconciliation..$^{23}$

Mediation makes it possible to constructively approach and effectively manage a conflict, and treats each problem as one that can be solved. Irrespective of the type of mediation, there is a procedure in effect in each of them. Mediation proceedings are of a step-by-step character. The following stages can be distinguished in the course of mediation:

I. The mediator familiarizes themselves with the case. The cases that are sent for mediation undergo an evaluation by the mediator. Its objective is to verify if there are factors that would exclude the possibility of mediation. These factors include: addiction to intoxicants, mental illnesses, mental retardation and violence. The mediator cannot offer mediation if the safety of either party is at risk, but in case of violence occurring in marriage or partnership they can help establish the conditions for a divorce while obeying the principle of balance between the parties. In line with the binding regulations, the mediator can also resign from offering mediation if:

either party has not consented to mediation or resigned from it in the course of mediation; the mediator personally knows the party that is to participate in mediation; it is difficult for the mediator to stay impartial; based on documents or conversations, it appears that one party is mentally ill or retarded (...); violence or alcoholism can influence the course of mediation or completion of the agreement conditions; the mediator has the right to resign from offering mediation if the parties do not agree on basic facts. $^{24}$

II. A preliminary meeting, called a preliminary mediation session where the mediator gives a monologue to present the rules of mediation and the role of the mediator. They answer the parties' questions so that the participants can take a decision about starting mediation, and they show the parties the benefits of mediation. They set the date of the joint mediation session with the participants. The first person invited to the preliminary meeting is the initiator of the mediation, also called the plaintiff. The mediator creates an opportunity for the parties to present both their needs and expectations. A socalled steering towards the future takes place, i.e. the best solution to solve the conflict that would be beneficial for both parties is sought. This stage is an attempt at viewing the conflict from the perspective of the other party, as well as stating what phase the other conflicted party is in. The task of the mediator

23 H. Karaszewska, Mediacja jako dobrowolny sposób, p. 421; Szkolenie z zakresu mediacji rodzinnych. Skrypt szkoleniowy, Ed. Polskie Centrum Mediacji, Warszawa 2018, p. 8.

24 Szkolenie z zakresu mediacji rodzinnych, p. 7. 
that will accompany them during the entire process of mediation is to listen to both parties. The mediator creates an atmosphere that allows to achieve three basic results. The first one is aimed at creating an atmosphere where the party feels that they have been heard and understood by the mediator. The second one is linked to the situation where the listening party understands the problems of the other party when they are presented by the mediator. The third one is for the parties to understand what behaviour is expected of them in the next phase of mediation. ${ }^{25}$

III. Joint mediation session/proper mediation. After recalling the rules of mediation and the role played by the mediator, and after setting the timeframe, the subject of mediation is defined. The parties present their points of view, seek satisfying solutions with the mediator's participation and, if possible, write down an agreement/ settlement. ${ }^{26}$ Seeking solutions is not an easy task for the parties. Each party will want to impose their own solutions. This is why the role of the mediator becomes so important, as they present common points, joint interests, issues that the parties perceive, approach or solve in the same way. There are emotions during the joint mediation session that make it impossible for the parties to objectively view the conflict. During this meeting, it is necessary for the mediator to underline that each party has the right to speak, present their point of view, and be treated with respect. If the parties work out a settlement, it is the role of the mediator to write the agreement down in a way that matches all formal and legal requirements, i.e. specific, measurable, attainable, realistic and timely. The mediator makes sure that the commitments made by parties can be realistically completed and are accepted voluntarily while being fully understood by the parties reaching the agreement. The settlement is supposed to serve the interests of both parties and it is important for the parties to be convinced about it. During mediation, the mediator uses techniques that bring the parties closer. The mediator uses normalization, i.e. they show that the parties' conflict is not something that happened only to them, and that it can be solved with the use of adequate measures in the course of a conversation. These techniques also include sharing, i.e. showing by the mediator that a given contentious issue is the parties' common problem, and not a problem of just one of the parties. Another technique is to focus on the future, i.e. present what the relations between the parties will be like if they reach an agreement or remain in conflict; resume what the parties say and make hypotheses about what happens during each session. The hypotheses

\footnotetext{
${ }^{25}$ Skarb mediatora. Wybór tekstów, Ed. R. Milewski, Warszawa 2016, p. 26.

${ }^{26}$ Szkolenie z zakresu mediacji rodzinnych, p. 5-6.
} 
make it possible for the mediator to ask accurate questions and focus on their professional relation with their clients. ${ }^{27}$

Mediation is more and more frequently used in proceedings on family cases such as divorce and separation, and related problems such as executing parental authority, regulating contacts between the parent and their child, and establishing child benefits. Taking into account their individual situation, the parties can detail, among others: the child's dwelling place, method and schedule of the parent's contacts with their child, methods of the child's contacts with other members of the family, participation in decisions on important subjects related to the child, e.g. selecting a school, profile of learning, healthcare, rules for upbringing and system of values that are to be transmitted to the child, rules for covering the cost of living and bringing the child up (i.e. the maintenance issue). ${ }^{28}$

The characteristics of a family conflict include: a multi-layered structure, frequently a long period of escalation and tension experienced by the parties and their children, affecting a close relationship of social and psychological importance. During its course, there are strong emotions that hinder or actually make it impossible to analyse the situation rationally; there is also frustration that results from the sense of loss of a relationship and the need to continue executing the role of a parent alone. ${ }^{29}$ According to A. Gójska and $\mathrm{V}$. Huryn, one of the basic difficulties that a family mediator comes across is the lack of the parties' experience in negotiation.

The parties are confronted with the ambiguity and novelty of two events: separation and participation in mediation. The first one is linked to the need to assimilate a lot of new information at once of financial (how are family finances organized, what are the financial consequences of adopting various solutions), legal (what is co-owned and what not; what is at-fault divorce and what are its consequences), and psychological character (what is it that I want for my sense of security, whom can I contact to receive support). What is more, when participating in mediation spouses are forced to behave in a way that is "unnatural" in a given situation. This means that it is necessary for them to participate in arrangements with their spouse in a joint, cooperative way, taking into account their further relationship as parents of their common children, being able to look after oneself when so far it has been the other party who looked after everything themselves; all this despite the undoubtedly antagonized relationship between them and negative emotions that accompany the situation. ${ }^{30}$

27 Skarb mediatora, p. 34.

${ }^{28}$ Czy tylko sad rozstrzyga o sporze? Mediacja i sadownictwo polubowne. Informator o alternatywnych sposobach rozwiazywania sporów, Ed. A. Rękas, Warszawa 2010, p. 22.

29 A. Gójska, Mediacja w sprawach rodzinnych. Mediacje w polskim systemie prawa, Warszawa 2011, p. 4-5.

${ }^{30}$ A. Gójska, V. Huryn, Mediacja w rozwiązywaniu konfliktów rodzinnych, Warszawa 2007, p. 64-65 after: A. Bieliński, A. Kaftańska, Kilka uwag, p. 28. 
Besides, the situation of divorce is recognized as one of the most serious life crises, and its consequences affect various life spheres of the divorcees and their family and friends (especially children). It may influence the functioning of the child in the school environment. What can be observed are, for example, changes in the child's behaviour, completion of school duties, and relationships with peers and teachers. Focused on themselves at that time, the spouses often treat the needs of their children as secondary and do not inform the school about the complicated situation at home that affects their child. Depending on their age, children react to the situation of their parents parting and related changes in their lives differently. Infants do not understand the situation; 2- or 3-year-old kids realize that one of their parents does not live at home but they are unaware why; kindergarten-age children sense their parents' negative feelings, such as anger or sadness, and the lack of one of their parents, yet they do not why it is like that, either; primary-school children start to understand what divorce is; teenagers who attend post-primary schools understand it fully, but most often do not accept the fact of their parents parting. ${ }^{31}$

Children and adults live through a divorce in a different way. Children do not treat it as a so-called second chance; it is a painful experience for them irrespective of how old they are. ${ }^{32}$ They do not understand the reasons behind it, especially if there were no open situations of aggression, conflict or violence. The child's previous world, sense of safety and stability are destroyed; the child feels lost, and a feeling of resentment, harm, anxiety and helplessness, as well as denial, may appear (fantasizing about spending time and holidays together etc.).

The child takes the blame for breaking their parents' marriage, which is often reflected in the child's attempts at saving their parents' marriage by sacrificing themselves, their time, changing their behaviour in the name of their parents coming back together. Taking the blame by the child is a burden that is impossible to handle and leads to difficulties in controlling emotions and aggression. Uncontrolled and aggressive behaviour often directed at the parent

${ }^{31}$ Based on: M. Tański et al., Dziecko w rozwodzie. Poradnik dla rodziców, Warszawa 2005, p. 6.

32 Some parents actually wait with their decision to divorce until their children become adults and go to the university, because they think that it will then be less painful and easier to live through for their children. Research conducted in the US (i.a. Judith p. Wallerstein, Jim Conway) proved that one's parents' divorce is one of the most important events in the life of a young adult in this period. The students who took part in the study expressed their doubts about building and maintaining a close relationship with another person having experienced the divorce of their parents. They even felt guilty due to them leaving home to go to the university and leaving their parents alone. J. Conway, Dorosłe dzieci rozwiedzionych rodziców. Jak uwolnić się od bolesnej przeszłości, Oficyna Wydawnicza Logos, Warszawa 1997, see after: M. Piotrowska, Rodzice i dzieci w trakcie i po rozwodzie: źródła wsparcia i pomocy, Studia Pedagogiczne. Problemy Społeczne, Edukacyjne i Artystyczne, 2012, 21, p. 81. 
who leaves (even if they are not to blame for the breakdown of their marriage) are transmitted to their peers, teachers and others (examples include destroying items and vandalism). The divorce has a significant influence over how the child is adjusted to school and positioned in their class. The child has a sense of being worse than their peers from complete families. Their anxiety and irritation increase; their ability to develop their talents decreases and there is a lack of school success. This period may also be accompanied by sleep problems, loss of appetite or refusal to eat, apathy, passivity, aggression that may be directed at others or oneself; in other words, symptoms of child and adolescent depression. Frequently, the difficulties experienced by the child at school are deliberate as the child believes that they can protect the family from falling apart in this way. Bad behaviour at school, worse marks and teachers' complaints create a problem that parents may analyse and tackle together. ${ }^{33}$

Divorce may also destroy social and psychological aspects of the process of passage to adulthood. In the period of puberty, which is a time of change, protest and shaping one's own identity, it may be particularly painful for a teenager. Behaviour such as criticism and negation of the world of adults that are characteristic of the period of adolescence, and the pursuit of independence all express teenagers' need for reliability and stability of their home and parents who should support them in this process. Divorce disturbs the possibility to fulfil the above-mentioned needs and violates the sense of security in young people. They build a negative approach to their parents' new partners and are afraid of building their own relationship with another person. The situation of a family breakdown also affects their school activity, successes, cultural and mental development, and interests. ${ }^{34}$

It is important to instruct spouses in the course of a mediation process that it is necessary to inform the educational institutions that their children attend about the divorce situation that they experience and - as a consequence about the possible behaviour as described above. This should influence the way the children are perceived by tutors and teachers, and help them provide assistance and didactic and educational activities.

After a divorce, the family reorganizes its functioning in various spheres of life. Parents often take an attitude of resignation, have lowered self-esteem and problems with self-acceptance, which hinders the appropriate upbringing of their child ${ }^{35}$ and passing on the desired patterns of social roles and

${ }^{33}$ More: M. Tański et al., Dziecko w rozwodzie; J. Jabłoński, Rozwód. Jak go przeżyć, Warszawa 2000.

${ }^{34}$ J. Jabłoński, Rozwód, p. 143 and n.

${ }_{35}$ Compare U. Sokal, Więzi uczuciowe dorostych dzieci z rodzicami w rodzinach rozwiedzionych, Elbląg 2005; M. Suchodolska, Relacje rodzice - dzieci w rodzinach rozwiedzionych z perspektywy dorostych dzieci, Pedagogika Rodziny, 2011, 1(2). 
attitudes. Psychologists and pedagogues started to observe long-term consequences of a child's parents getting divorced for the child's future functioning as an adult, its influence on the development of the emotional sphere, social life and relationships also in their own family. The ACOD (Adult Children of Divorce) term was coined to refer to adults who lived through their parents' divorce and display a set of characteristic features. ${ }^{36}$

Parents' divorce is often linked to changing one's dwelling place, life environment of the child, and as a result their school or peer group that the child has built and maintained satisfying relationships with, and from which they received support in the situation of a disturbance in the balance of their family environment. One can say that the situation of a child whose parents get a divorce belongs to the group of crisis situations. The child has to adapt to the conditions of their "new life" that they come across and that are difficult to accept.

The awareness of the above factors is also important for educational institutions (the child's kindergarten or school) that take part in the process of the child's socialization and upbringing. When observing undesired and alarming changes in the child's behaviour, such as impulsive and aggressive reactions, focus problems, absent-mindedness and worse learning results, tutors, teachers and school pedagogues search for their origins in order to implement assistance that is aimed at hindering the process of social maladjustment. For the child's best interest, parents should inform the school about the result of the mediation proceedings as far as its conclusions referring to the child's functioning at school are concerned, including the issues that are crucial for completing the school duty.

The topics related to family mediation are regulated by the Code of Civil Proceedings $\operatorname{act}^{37}$ and the Family and Guardianship Code act. The former defines the rules for mediation in all civil disputes; the lawmaker also underlines the possibility and legitimacy of mediation in disputes that are a consequence of a family breakdown. The court can thus send spouses for mediation if there are prospects of saving the marriage (in order to reconcile the spouses as defined in art. $436 \S 2$ of k.p.c.). The parties who decided to dissolve their marriage through a divorce can use mediation to agree on the rules for their parting via mediation: ways of satisfying family needs (alimony), executing parental authority after divorce, contacts with their children and property issues (art. 4451 of k.p.c.).

${ }^{36}$ World research showed that long-term consequences of a divorce can determine the adult life of children from broken families: J. Wallerstein, p. Blakeslee, J. Conway, J. Brągiel, U. Sokal, M. Piotrowska.

37 Act of 17 November 1964 Kodeks postępowania cywilnego [Code of Civil Proceedings] (Journal of Law 2018 item 1360 with changes) 
Leaving the priority in arrangements regarding the situation of the child after divorce with the parents, the regulations of the Family and Guardianship Code underline that the Court takes the spouses' written agreement on the way of executing their parental authority and maintaining contact with their children after the divorce into account provided that its stipulations align with the child's best interest. ${ }^{38}$ For the best interest of their children, the spouses/parents who separate should agree on the rules for their cooperation as far as executing their rights and duties towards the child is concerned. It is best if they agree on a Plan of Parental Care (also called a Parenting Plan) ${ }^{39}$ themselves, because it states how each of them is going to function. Above all, it refers to the child's dwelling place and contacts with the other parent. It indicates, among others: the child's main dwelling place; schedule of meetings with the other parent; child's communication with parents outside the time that they spend together (phone, Internet); rules for meeting the other parent, as well as, for example, their grandparents, i.e. the child's contacts with other people; parents' participation in important decisions referring to their child; upbringing rules; parents' participation in the child's cost of living; healthcare; way of taking current decisions and modifying the Plan of Parental Care.

Apart from the differences, there are many similarities that can be indicated between mediation and a court trial, i.a. there is a dispute and there are attempts at solving it, among others. A court trial is governed by given procedures, and a case settlement is imposed by given regulations. The court settles disputes, whereas the mediation process solves disputes. The difference is not only semantic, although weight is attached to the language used to describe the two in order to avoid narration about confrontation, opposition or process formalization. In case of mediation, it is less frequent to talk about a procedure or proceedings; more often, the notion of method is used. In mediation, the basis for decisions are the interests and desires of the parties that refer to the future; solving is based on the rule of the present/future. In court, the basis are the facts from the past and the settlement is based on the rule of the past/present. In mediation, decisions are worked out by the participants and are of autonomous character, whereas in court they come from subjects that are outside the conflict and are of heteronomic character. The parties of mediation can control its course as well as the results of the decisions taken, whereas in court it is the subject who settles the dispute that has control over the course of the conflict and its settlement. What is incredibly important for the participants of the proceedings is that in mediation the "win-win solution", i.e. I win - you win, paradigm dominates. On the contrary, it is the "win-lose

38 Art. $58 \S 1$ of the Act of 25 February 1964 Kodeks rodzinny i opiekuńczy [Family and Guardianship Code] (Journal of Law 2017 item 682 with changes).

${ }^{39}$ Czy tylko sad rozstrzyga o sporze? p. 33. 
solution" paradigm, I win - you lose, that dominates in a court procedure. Thus in mediation, consensus is sought and the parties do not have the sense of discomfort, defeat or failure. ${ }^{40}$

As a result of the above, mediation is a great opportunity for the parties of a conflict to make an attempt at jointly solving it, feeling that they influence the decisions made and take responsibility for their consequences. With the help of a mediator, mediation makes it possible to work out solutions that are acceptable for the parties and that are a result of taking the view of the other party on the problem into account. It allows to have a dialogue despite a conflict and gives hope that the relationship can be settled under circumstances that are difficult and would seem insolvable at first glance.

\section{BIBLIOGRAPHY}

Bieliński A., Kaftańska A., Kilka uwag na temet mediacji rodzinnych, Kwartalnik ADR, 2011, 3. Bobrowicz M., Mediacje gospodarcze - jak mediować i przekonywać, Wydawnictwo C.H. Beck, Warszawa 2004.

Byra S., Konflikt interpersonalny - istota i funkcje, [in:] Profesjonalny mediator. Zostań nim. Poradnik metodyczny, Ed. A. Lewicka, Wydawnictwo UMCS, Lublin 2008.

Conway J., Doroste dzieci rozwiedzionych rodziców. Jak uwolnić się od bolesnej przeszłości, Oficyna Wydawnicza Logos, Warszawa 1997.

Czy tylko sąd rozstrzyga o sporze? Mediacja i sądownictwo polubowne. Informator o alternatywnych sposobach rozwiazywania sporów, Ed. A. Rękas, Warszawa 2010.

Gmurzyńska E., Morek R., Wprowadzenie, [in:] Mediacje. Teoria i praktyka, Wydawnictwo Wolters Kluwer, Warszawa 2009.

Groszyk H., Korybski A., Konflikt interesów i praw, Centralny Ośrodek Metodyczny Studiów Nauk Politycznych, Warszawa 1990.

Gójska A., Mediacja w sprawach rodzinnych. Mediacje w polskim systemie prawa, Ministerstwo Sprawiedliwości, Warszawa 2011.

Gójska A., Huryn V., Mediacja w rozwiązywaniu konfliktów rodzinnych, Wydawnictwo C.H. Beck, Warszawa 2007.

Grudziewska E., Lewicka-Zelent A., Kompetencje mediacyjne w profesji pracownika socjalnego, Warszawa 2015

Jabłoński J., Rozwód. Jak go przeżyć, Wydawnictwo W.A.B., Warszawa 2000.

Kalisz A., Zienkiewicz A., Mediacja sądowa i pozasadowa. Zarys wykładu, Wydawnictwo Wolters Kluwer, Warszawa 2009.

Karaszewska H., Mediacja jako dobrowolny sposób rozwiązywania konfliktów w rodzinie, [in:] Horyzonty pedagogiki resocjalizacyjnej. Księga Jubileuszowa Profesora Wiesława Ambrozika, Eds. A. Barczykowska, M. Muskała, Wydawnictwo Naukowe UAM, Poznań 2017.

Kodeks Etyki Mediatora, Polskie Centrum Mediacji, Warszawa 2006.

Kuć M., Wiktymologia, Wydawnictwo C.H. Beck, Warszawa 2010.

${ }^{40}$ P. Sołtysiak, Mediacja jako alternatywna metoda rozwiązywania sporów, Zeszyty Naukowe Instytutu Administracji AJD w Częstochowie, 2012, 2(6), p. 12-14 based on: H. Groszyk, A. Korybski, Konflikt interesów i praw, Warszawa 1990, A. Żuk, Konflikt i walka, Lublin 1996. 